\title{
Potential use of industrial wastes in the treatment of mine wastes: A case study of legacy mine sites in Tasmania
}

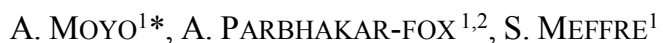
AND D.R. COOKE ${ }^{1}$

${ }^{1}$ ARC Research Hub for Transforming the Mining Value Chain \& Centre for Ore Deposit and Earth Sciences, University of Tasmania, Hobart, Tasmania 7001, Australia (*correspondence: annah.moyo@utas.edu.au, sebastien.meffre@utas.edu.au, d.cooke@utas.edu.au)

${ }^{2}$ WH Bryan Mining and Geology Research Centre, The University of Queensland, Indooroopilly, QLD 4068, Australia (a.parbhakarfox@uq.edu.au)

\section{AMD Treatment Method}

Carbonate and hydroxide-bearing industrial wastes can potentially treat acid and metalliferous drainage (AMD) produced via the oxidation of sulfide-bearing mining wastes. The potential use of green liquor dregs (GLD), wood ash, coal ash, red mud as well as scallop, mussel and oyster shells as AMD remedies for six mine sites in Tasmania was evaluated using mineralogical and geochemical analyses. A new benchscale accelerated kinetic leach test was developed using $55 \mathrm{~mm}$ diameter Buchner funnels. 82 cells including controls were established with each funnel filled with $20 \mathrm{~g}$ in a 7:3 weight ratio of milled $(<75 \mu \mathrm{m})$ mine waste to industrial waste (both blended and as cover layers). The cells were irrigated with deionized water every second day for 1 month and after every 10 days thereafter until 100 days had elapsed.

\section{Discussion of Results}

The initial geochemical characterization classified the untreated mine wastes as potentially acid-forming and the industrial wastes as acid neutralizing with net acid generation (NAG) $\mathrm{pH}$ values ranging from $\mathrm{pH} 1.9$ to 5 and $\mathrm{pH} 5.8$ to 10.1 respectively. Blending of the industrial and mine wastes was most effective for acid neutralization, however, the $\mathrm{pH}$ difference when compared to multi-layering and top covering was mostly $<1.0 \mathrm{pH}$ unit. Overall, GLD showed the greatest capacity for treating AMD, whilst the wood ash was least effective. Our findings highlight that there are potential benefits in using industrial waste for AMD control (e.g., codisposal of waste, environmental and economic sustainability). However, the potential applicability of local industrial wastes as AMD ameliorates requires site-specific investigations. 